\title{
ANALISIS BIAYA PEMASARAN DAN PROFITABILITAS BERDASARKAN JENIS PRODUK PADA PT. KENDARI BINTANG LESTARI CABANG BAUBAU
}

\author{
Nining Asniar Ridzal \\ Program Studi Akuntansi, Fakultas Ekonomi \\ Universitas Muhammadiyah Buton, Baubau, Indonesia \\ Email: nining.asniar@umbuton.ac.id
}

\begin{abstract}
ABSTRAK
Biaya pemasaran adalah meliputi semua biaya yang terjadi sejak barang selesai diproduksi dan disimpan dalam gudang dan barang tersebut dirubah kembali dalam bentuk yang tunai. Profitabilitas adalah Penghasilanyangdiinginkanoleh perusahaandalammenjual produknyapadaperiodeakuntansitertentu. Penelitian ini bertujuan untuk mengetahui berapa besar biaya pemasaran dan alokasi biaya pemasaran setiap jenis produk serta seberapa besar profitabilitas yang didapat dari tiap jenis produk. Berdasarkan hasil analisis data maka kesimpulan dari penelitian ini adalah :Alokasi biaya pemasaran setiap jenis produk berdasarkan fungsi pemasaran untuk periode tahun 2013 sampai 2015 cenderung selalu mengalami peningkatan.Berdasarkan uraian analisa biaya pemasaran dan profitabilitas berdasarkan jenis produk dapat diketahui bahwa biaya pemasaran yang telah dikeluarkan oleh PT. Kendari Bintang Lestari belum dikelola dengan baik.Hal ini terlihat bahwa biaya yang keluar untuk kegiatan pemasaran banyak digunakan untuk kebutuhan karyawan, sedangkan untuk produk hanya sedikit.Dari analisa profitabilitas berdasarkan jenis produk dapat diketahui bahwa produk springbed lebih menguntungkan perusahaan.
\end{abstract}

\section{Kata Kunci : Biaya Pemasaran, Profitabilitas, Jenis Produk.}

\section{ABSTRACT}

Marketing costs include all costs incurred from the time the goods are finished being produced and stored in the warehouse and the goods are changed back in cash. Profitability is income desired by the company in selling its products in a certain accounting period.

This study aims to find out how much marketing costs and marketing costs allocation for each type of product and how much profitability is obtained from each type of product. Based on the results of data analysis, the conclusions from this study are: allocation of marketing costs for each type of product based on the marketing function for the period 2013 to 2015 tends to always increase. Based on the description of marketing cost analysis and profitability based on product types, it can be seen that the marketing costs incurred by PT Kendari Bintang Lestari has not been managed properly. It is seen that the costs incurred for marketing activities are mostly used for the needs of employees, while for products only a little. From the profitability analysis based on the type of product it can be seen that springbed products are more profitable for the company.

Keywords: Marketing Costs, Profitability, Product Type 


\section{PENDAHULUAN}

Pada dasarnya tujuan didirikannya suatu perusahaan adalah memperoleh laba tertentu guna menjaga kelangsungan hidup perusahaan. Usaha memperoleh laba adalah menjadi tanggungan pihak manajemen harus berusaha sebaik-baiknya dalam melaksanakan kegiatan perusahaan. Semakin maju dan berkembang dunia usaha maka semakin ketat persaingan antar perusahaan dalam mempertahankan keuntungan atau paling tidak mempertahankan penjualan. Salah satu cara perusahaan adalah menyeimbangkan produksi dengan pemasaran.

Konsep pemasaran adalah suatu falsafah bisnis yang menyatakan bahwa kepuasan kebutuhan konsumen merupakan syarat ekonomi dan sosial bagi kelangsungan hidup perusahaan [1]. Konsep pemasaran juga merupakan suatu paham yang beranggapan bahwa penentuan suatu kebutuhan dan keinginan konsumen menjadi sasaran bagi penjualan, merupakan tugas utama dari perusahaan dan bahwa perusahaan harus menjalankan usaha sedemikian rupa sehingga dapat menyampaikan kepuasan yang diinginkan para konsumen dengan cara yang lebih efektif dan lebih efisien. orientasi konsumen, koordinasi dan integrasi dalam perusahaan serta mendapatkan laba melalui kepuasan konsumen adalah faktor penting sebagai dasar dalam konsep pemasaran [2].

Pemasaran merupakan proses perencanaan dan pelaksanaan konsep, penentuan harga, promosi dan pendistribusian gagasan barang dan jasa organisasi dan peristiwa untuk menciptakan dan memelihara hubungan yang memuaskan tujuan perorangan dan organisasi [3]. Definisi lain dari Pemasaran adalah proses sosial yang didalamnya individu dan kelompok mendapatkan apa yang mereka butuhkan dan inginkan dengan menciptakan, menawarkan dan secara bebas mempertukarkan produk yang bernilai dengan pihak lain [4].

Ukuran yang seringkali dipakai untuk menilai sukses tidaknya suatu perusahaan adalah dari laba yang diperoleh perusahaan, besarnya laba yang dipengaruhi oleh harga jual produk dan biaya pemasaran serta kemampuan menjual produknya. Laba merupakan ringkasan hasil bersih aktivitas operasi 
usaha dalam periode tertentu yang dinyatakan dalam istilah keuangan [5]. Laba adalah ukuran pokok keseluruhan keberhasilan perusahaan [6]. Sebagai langkah awal untuk mencapai tujuan perusahaan, maka seorang manajer pemasaran terlebih dahulu harus membuat perencanaan, karena pada umumnya perencanaan pemasaran merupakan kunci pokok untuk keberhasilan usaha pemasaran pada suatu perusahaan. Kegiatan pemasaran dimulai tidak hanya pada saat produksi selesai, tetapi dimulai sejak sebelum barang diproduksi dan tidak berakhir dengan penjualan [7].

Sebagai tahap akhir dari fungsi manajemen adalah mengadakan pengawasan terhadap kegiatan pemasaran. Agar manajemen dapat menjalankan fungsinya dengan baik mereka harus mempunyai informasi lengkap mengenai seluruh rangkaian kegiatan yang berkaitan erat dengan masalah-masalah pemasaran, termasuk juga informasi mengenai biaya pemasaran karena volume penjualan yang tinggi saja belum merupakan ukuran keberhasilan suatu perusahaan, apabila tanpa memperhitungkan seberapa besar biaya-biaya yang diperlukan untuk aktivitas pemasarannya.

Biaya pemasaran produk merupakan biaya-biaya yang terjadi untuk melaksanakan kegiatan pemasaran produk meliputi biaya iklan, biaya promosi, biaya angkut penjualan, gaji bagian pemasaran, dan lain sebagainya $[8]$.

Apabila biaya pemasaran ini tidak diperhitungkan dengan benar, perusahaan akan kehilangan sebagian kesempatan mencapai tingkat laba yang diharapkan. Analisis biaya pemasaran sangat bermanfaat dalam evaluasi dan mengendalikan kegiatan pemasaran produk perusahaan, terutama pada perusahaan yang memproduksi produk lebih dari satu macam. Untuk itu perusahaan perlu mengadakan analisa biaya pemasaran untuk menentukan efisiensi biaya pemasaran berdasarkan produk tersebut. Dalam analisa biaya pemasaran akan dibahas secara mendalam tentang masalah biaya operasional perusahaan yang tercermin pada laporan rugi laba perusahaan. Selain itu akan ditentukan besarnya alokasi biaya pemasaran untuk setiap elemen yang ada pada setiap bagian pemasaran. 
Di satu sisi banyak perusahaan yang sedang mengembangkan produknya ke pasaran kurang memperhatikan analisis biaya pemasaran. Hal ini menyebabkan laba yang diperoleh perusahaan kurang efektif, karena biayabiaya yang tidak dikendalikan.Usaha pemasaran yang baik sangat berpengaruh terhadap volume penjualan produk. Promosi, saluran distribusi serta kegiatan pemasaran lainnya harus dilaksanakan dengan baik. Biaya yang timbul sebagai akibat dari pemasaran produk ini harus dikontrol agar tidak terlalu rendah juga tidak terlalu tinggi. Dengan demikian perusahaan dapat memperoleh laba yang diharapkan, [8].

PT. Kendari Bintang Lestari (PT.KBL) atau Olympic Group manajemen merupakan perusahaan yang bergerak dibidang trading furniture atau perdagangan furniture. Mulai dari memproduksi barang furniture hingga menjual barang furniture, dimana barang furniture yang dimaksud adalah barang perabot rumah tangga hingga perabot kantoran seperti kursi, meja, lemari, springbed dan lain - lain.

PT. Kendari Bintang Lestari (PT.KBL) didirikan pada tanggal 23 Mei 2002 dan masih tergolong sebagai perusahaan muda yang baru saja menjajaki dunia trading furniture, namun karena dijalankan oleh para profesional yang sudah berpengalaman di dunia furniture maka PT. Kendari Bintang Lestari (PT.KBL) dapat dikatakan cukup sukses. Terbukti pada tahun 2013 PT. Kendari Bintang Lestari (PT.KBL) sudah memiliki lebih dari 20 cabang yang tersebar di seluruh indonesia, yaitu: Bali, Balikpapan, Bandung, Bogor, Jakarta, Jambi, Kendari, Lampung, Mataram, Makassar, Malang, Manado, Padang, Palembang, Palu, Kupang, Pekanbaru, Samarinda, Semarang, Surabaya dan Yogyakarta.Untuk menyalurkan barang, memperluas barang atau memperluas daerah pemasaran PT. Kendari Bintang Lestari (PT.KBL) mendirikan anak perusahaan yang tiap daerahnya mengacu pada nama daerah tersebut, salah satunya yaitu PT. Kendari Bintang Lestari (PT.KBL) yang berada di wilayah Kendari Sulawesi Tenggara.

PT. Kendari Bintang Lestari (PT.KBL) mempunyai satu cabang di wilayah Kota Baubau Sulawesi Tenggara, penjualan yang ditargetkan PT. 
Kendari Bintang Lestari (PT.KBL) cabang Baubau kepada pihak marketing setiap bulannya selalu mengalami perubahan. Perubahan target penjualan tersebut bukannya selalu meningkat, melainkan perubahan target penjualan yang mengalami naik turun setiap bulannya. Untuk itu penelitian ini akan berfokus pada analisis biaya pemasaran dan profitabilitas berdasarkan jenis produk pada PT Kendari Bintang Lestari Cabang Baubau. Adapun pertanyaan yang diajukan dalam penelitian ini adalah "berapa besar biaya pemasaran dan alokasi biaya pemasaran setiap jenis produk?" serta "Seberapa besar profitabilitas yang didapat dari tiap jenis produk?".

Berdasarkan permasalahan diatas maka tujuan dari penelitian ini adalah Untuk mengetahui berapa besar biaya pemasaran dan alokasi biaya pemasaran setiap jenis produk dan Untuk mengetahui seberapa besar profitabilitas yang didapat dari tiap jenis produk.

\section{METODE PENELITIAN}

\section{Jenis dan Sumber Data}

Jenis Data terbagi atas dua yaitu data kualitatif dan data kuantitatif. Data kualitatif adalah data yang dinyatakan dalam bentuk angka dan kalimat. Sedangkan data kuantitatif adalah data yang berbentuk angka atau data kualitatif yang diangkakan [9]. Adapun Jenis data yang digunakan dalam penelitian ini adalah data kuantitatif dan data kualitatif. Data kuantitatif adalah jenis data yang berbentuk angka-angka.adapun data kuantitatif berupa biaya pemasaran, laporan neraca dan rugi laba. Data kualitatif adalah jenis data yang berbentuk informasi dan penjelasan dari pimpinan perusahaan dan karyawan mengenai sejarah singkat perusahaan dan struktur organisasi yang digunakan oleh perusahaan.

Sumber data dibedakan menjadi dua yaitu data primer dan data sekunder. Data primer adalah sumber data penelitian yang diperoleh secara langsung dari sumber asli, sedangkan data sekunder adalah sumber data yang diperoleh secara tidak langsung melalui media perantara [10]. Sumber data yang digunakan dalam penelitian ini adalah data primer dan data sekunder. 
Data primer adalah sumber data yang diperoleh langsung yaitu dari PT.Kendari Bintang Lestari dan segenap karyawan yang ada, baik hasil wawancara pengamatan, maupun yang diperoleh dari pencatatan perusahaan.Data sekunder adalah data yang diperoleh dari literatur atau bahan lainnya yang berhubungan dengan penelitian ini.Data ini digunakan untuk mendukung informasi primer yang telah diperoleh yaitu berupa struktur organisasi, bahan pustaka, literatur, penelitian terdahulu, buku dan lain sebagainya.

\section{Metode Pengumpulan Data}

Metode yang digunakan dalam mengumpulkan data ada tiga yaitu wawancara, dokumentasi, dan studi pustaka. Wawancara dilakukan dengan mengadakan tanya jawab langsung dengan pimpinan perusahaan dan staf karyawan yang ada.Dokumentasi yaitu teknik yang digunakan melalui pengkajian dokumendokumen atau catatan-catatan yang diperoleh dari perusahaan. Studi pustaka yaitu metode pengumpulan data dengan cara membaca buku-buku dan mengikuti petunjuk-petunjuk serta teori-teori pada literatur yang berkaitan dengan objek yang diteliti.

\section{Analisis Data}

Secara umum analisis data yang digunakan adalah secara kualitatif dan kuantitatif. Analisis kualitatif yaitu cara untuk mendukung dan mempertegas dari perhitungan secara kuantitatif yang digambarkan dengan kata atau kalimat yang terpisah. Analisis kualitatif digunakan untuk menjelaskan analisis biaya pemasaran dan profitabilitas berdasarkan jenis produk.

Teknik analisis biaya pemasaran berdasarkan jenis produk :

1. Untuk menganalisis alokasi biaya pemasaran setiap jenis produk dapat dilakukan dengan menggunakan tahap-tahap sebagai berikut :

a. Menggolongkan jenis biaya pemasaran menurut fungsinya [11].

b. Menentukan dasar alokasi biaya pemasaran dari tiap fungsi kedalam masing-masing produk [8] 
c. Menentukan tarif alokasi biaya pemasaran dengan cara membagi tiaptiap fungsi biaya pemasaran dengan dasar alokasinya.

d. Menentukan alokasi biaya pemasaran tiap produk dengan jalan mengalikan dasar alokasi pada tiap produk tersebut dengan tarif alokasi setiap fungsi biaya pemasaran.

2. Analisis profitabilitas pemasaran berdasarkan jenis produk dengan langkah-langkah sebagai berikut :

a. Menggolongkan penghasilan penjualan kedalam setiap jenis produk

b. Menggolongkan harga pokok penjualan untuk setiap jenis produk

c. Menghitung laba kotor atas penjualan setiap jenis produk

d. Menghitung profit margin. Profit margin = \begin{tabular}{rrrrr}
$P$ & $B r$ & $n-H$ & $P$ & $P$ \\
\hline$S$
\end{tabular}

e. Mengalokasikan biaya pemasaran setiap fungsi pada setiap jenis produk

f. Menghitung laba bersih setiap jenis produk :

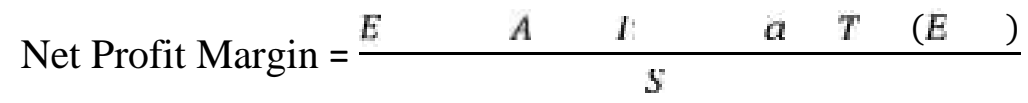

\section{HASIL DAN PEMBAHASAN}

\section{Hasil Penelitian}

PT. Kendari Bintang Lestari (PT.KBL) atau Olympic Group manajemen merupakan perusahaan yang bergerak dibidang trading furniture atau perdagangan furniture. Mulai dari memproduksi barang furniture hingga menjual barang furniture, dimana barang furniture yang dimaksud adalah barang perabot rumah tangga hingga perabot kantoran seperti kursi, meja, lemari, springbed dan lain - lain. Alokasi biaya pemasaran setiap jenis produk berdasarkan fungsi pemasaran untuk periode tahun 2013 sampai 2015 cenderung selalu mengalami peningkatan. Namun biaya pemasaran yang telah dikeluarkan oleh PT. Kendari Bintang Lestari belum dikelola dengan baik. 


\section{Pembahasan}

1) Biaya Pemasaran

Dari hasil analisis data biaya pemasaran diketahui bahwa biaya pemasaran setiap tahunnya mengalami kenaikan. Biaya yang paling tinggi terjadi pada tahun 2015 yaitu sebesar Rp. 839.658.000,- dan yang paling rendah terjadi pada tahun 2013 yaitu sebesar Rp. 661.339.000,-

2) Mengetahui Alokasi Biaya Pemasaran

Alokasi biaya pemasaran pada masing-masing produk dapat diketahui dengan langkah-langkah, diantaranya: menggolongkan jenis biaya pemasaran menurut fungsinya, menentukan dasar alokasi biaya pemasaran dari setiap fungsi ke dalam masing-masing produk, menentukan tarif alokasi biaya pemasaran, mengalikan dasar alokasi pada masing-masing produk tersebut dengan tarif alokasi biaya pemasaran setiap fungsi.

a. Menggolongkan Jenis Biaya Pemasaran

Biaya pemasaran menurut fungsi promosi dan advertensi meliputi gaji karyawan bagian promosi, biaya iklan, biaya pameran, biaya promosi, biaya contoh dan biaya diskon. Biaya penjualan meliputi gaji karyawan penjualan, biaya sewa kantor, komisi penjualan, dan biaya perjalanan dinas. Biaya pengepakan dan pengiriman meliputi gaji karyawan bagian pengepakan, biaya bahan pembungkus, ongkos angkut pengiriman, biaya penyusutan kendaraan, biaya pemeliharaan kendaraan, dan biaya operasi kendaraan.Biaya pergudangan dan penyimpanan meliputi gaji karyawan gudang, biaya penyusutan gudang, biaya penyimpanan, biaya pemeliharaan gudang, dan biaya yang dikeluarkan untuk pemeliharan gudang.biaya administrasi pemasaran meliputi gaji karyawan bagian administrasi pemasaran, biaya telepon, biaya kantor, dan biaya listrik kantor.

Selain penggolongan biaya pemasaran pada masing-masing jenis produk, biaya pemasaran juga dapat digolongkan menurut jenis biaya, yaitu biaya langsung dan biaya tidak langsung, penggolongan 
biaya pemasaran yang didasarkan atas masing-masing biaya langsung menurut fungsinya.

Pada PT. Kendari Bintang Lestari Cabang Baubau, biaya promosi dan advertensi langsung dikeluarkan oleh perusahaan selama tahun 2013-2015 meliputi biaya megatrone dan baliho. Biaya penjualan langsung yang dikeluarkan oleh perusahaan selama tahun 2013-2015 meliputi gaji karyawan bagian penjualan dan biaya perjalanan

Biaya pergudangan yang dikeluarkan oleh perusahaan selama tahun 2013-2015 meliputi gaji karyawan bagian gudang, biaya listrik sebagai penerangan gudang.Biaya administrasi langsung yang dikeluarkan oleh perusahaan selama tahun 2013-2015 meliputi gaji karyawan bagian administrasi pemasaran, biaya telepon, dan biaya pemakaian listrik kantor.

Alokasi biaya pemasaran tidak langsung dapat diketahui dengan cara membagi biaya pemasaran tidak langsung dengan jumlah karyawan bagian pemasaran dan mengalikannya dengan banyaknya karyawan masing-masing fungsi.

Berdasarkan hasil perhitungan alokasi biaya pemasaran tak langsung tahun 2013 adalah sebesar Rp. 264.204.000 dengan rincian sebagai berikut: untuk jenis biaya promosi dan advertensi dengan jumlah karyawan 1 orang, alokasi biayanya sebesar Rp. 22.017.000, jenis biaya penjualan dengan jumlah karyawan 4 orang, alokasi biayanya sebesar Rp. 88.067.999,- jenis biaya pergudangan dengan jumlah karyawan 5 orang, alokasi biayanya sebesar Rp. 110.085.000,-jenis biaya administrasi pemasaran dengan jumlah karyawan 2 orang, alokasi biayanya sebesar Rp. 44.034.000,-

Untuk alokasi biaya pemasaran tak langsung tahun 2014 adalah sebesar Rp. 285.769.000 dengan rincian untuk jenis biaya promosi dan advertensi dengan jumlah karyawan 1 orang, alokasi biayanya sebesar Rp. 23.814.083, jenis biaya penjualan dengan jumlah 
karyawan 4 orang, alokasi biayanya sebesar Rp. 95.256.333,- jenis biaya pergudangan dengan jumlah karyawan 5 orang, alokasi biayanya sebesar Rp. 119.070.417,-jenis biaya administrasi pemasaran dengan jumlah karyawan 2 orang, alokasi biayanya sebesar Rp. 47.628.167,--

Sedangkan alokasi biaya pemasaran tak langsung tahun 2015 adalah sebesar Rp. 353.628.000 dengan rincian sebagai berikut: untuk jenis biaya promosi dan advertensi dengan jumlah karyawan 1 orang, alokasi biayanya sebesar Rp. 29.469.000, jenis biaya penjualan dengan jumlah karyawan 4 orang, alokasi biayanya sebesar Rp. 117.876.000,- jenis biaya pergudangan dengan jumlah karyawan 5 orang, alokasi biayanya sebesar Rp. 147.345.000,-jenis biaya administrasi pemasaran dengan jumlah karyawan 2 orang, alokasi biayanya sebesar Rp. 58.938.000,--

Pada alokasi biaya pemasaran tak langsung dapat diketahui bahwa fungsi pergudangan selalu memiliki alokasi biaya tertinggi pada tahun 2013 sebesar Rp. 110.085.000,-, pada tahun 2014 sebesar Rp. 119.070.417,-, dan pada tahun 2015 sebesar Rp. 147.345.000,- . Besarnya alokasi biaya pemasaran tak langsung pada fungsi ini karena pada fungsi ini memiliki karyawan yang paling banyak dibanding dengan fungsi lainnya.

Pada perhitungan alokasi biaya langsung dan tak langsung pada masing-masing fungsi pemasaran, kita dapat mengetahui berapa besarnya alokasi total pada masing-masing fungsi pemasaran dengan cara menjumlah biaya pemasaran langsung tiap fungsi pemasaran dengan alokasi biaya pemasaran tak langsung tiap fungsi pada masing-masing fungsiDari hasil perhitungandiketahui bahwa sebagian besar biaya pemasaran pada masing-masing fungsi pemasaran mengalami peningkatan setiap tahunnya, biaya pemasaran yang sebesar Rp. 661.339.000 pada tahun 2013 menjadi Rp. 699.104.000, peningkatan cukup tajam terjadi pada tahun 2015. 
b. Menentukan Dasar Alokasi Biaya Pemasaran

Selanjutnya menentukan dasar alokasi biaya pemasaran adalah pembebanan biaya-biaya pemasaran kedalam tiap-tiap fungsi pemasaran dengan dasar alokasi yang adil agar tiap bagian menerima beban yang wajar. Dasar alokasi biaya pemasaran ke dalam setiap fungsi pemasaran adalah sebagai berikut.

$\begin{array}{cll}\text { No } & \begin{array}{l}\text { Biaya Menurut Fungsi } \\ \text { Pemasaran }\end{array} & \text { DasarAlokasi } \\ \text { 1. } & \text { Biaya Promosi dan Advertensi } & \text { Unit Terjual } \\ \text { 2. } & \text { Biaya Penjualan } & \text { Hasil Penjualan } \\ \text { 3. } & \text { Biaya Pergudangan } & \text { Unit Terjual } \\ 4 & \text { Biaya Administrasi Pemasaran } & \text { Frekuensi Penjualan }\end{array}$

c. Menentukan Tarif Alokasi Biaya Pemasaran

Setelah dasar untuk mengalokasikan biaya pemasaran ditentukan, selanjutnya menghitung tarif alokasi biaya pemasaran untuk tiap jenis produk yang perhitungannya dengan jalan membagi jumlah biaya pemasaran dengan dasar alokasinya sebagai berikut.

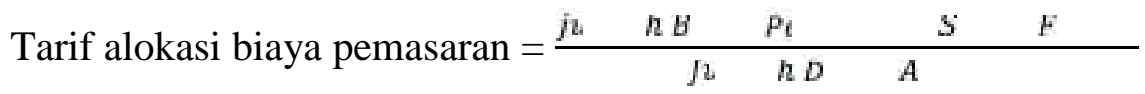

Dari perhitungan data biaya dapat diketahui bahwa tarif alokasi biaya pemasaran bagian penjualan mengalami penurunan yaitu pada tahun 2013 sebesar 0,016 menjadi 0,015 di tahun 2014 dan menjadi 0,010 pada tahun 2015 .

d. Biaya Pemasaran Setiap Jenis Produk

Biaya pemasaran setiap jenis produk dapat diketahui dengan cara mengalikan dasar alokasi yang terjadi pada setiap jenis produk dengan tarif alokasi biaya pemasaran masing-masing fungsi. Biaya pemasaran yang terjadi pada produk lemari pakaian, meja rias, meja makan, meja kerja, kursi, spring bad.

Dari hasil perhitungan biaya pemasaran per jenis produk diketahui bahwa alokasi biaya pemasaran untuk produk lemari pakaian pada tahun 2013-2015 mengalami perubahan yang 
cenderung meningkat. Pada tahun 2013 biaya pemasaran yang terjadi adalah sebesar Rp. 105.898.140, tahun 2014 meningkat menjadi Rp. 107.622.632, dan tahun 2015 meningkat menjadi Rp. 127.036.654,--

Untuk alokasi biaya pemasaran produk meja rias pada tahun 2013-2015 mengalami peningkatan. Pada tahun 2013 biaya pemasaran yang terjadi adalah sebesar Rp. 55.975.156, tahun 2014 meningkat menjadi Rp. 69.003.167, dan tahun 2015 meningkat menjadi Rp. 93.228.153,-. Aalokasi biaya pemasaran untuk produk meja makan tahun 2013-2015 mengalami perubahan. Pada tahun 2013 biaya pemasaran yang terjadi adalah sebesar Rp. 48.865.075, tahun 2014 meningkat menjadi Rp. 52.012.918, dan tahun 2015 meningkat menjadi Rp. 63.548.392,--

Alokasi biaya pemasaran untuk produk meja kerja pada tahun 2013-2015 mengalami perubahan, perubahan ini juga cenderung meningkat. Pada tahun 2013 biaya pemasaran yang terjadi adalah sebesar Rp. 59.847.597, tahun 2014 meningkat menjadi Rp. 65.936.389, dan tahun 2015 meningkat menjadi Rp. 83.267.334,--. Begitu pula dengan alokasi biaya pemasaran untuk produk kursi tahun 2013-2015 mengalami perubahan sebagai berikut : Pada tahun 2013 biaya pemasaran yang terjadi adalah sebesar Rp. 70.800.430, tahun 2014 meningkat menjadi Rp. 85.700.928, dan tahun 2015 meningkat menjadi Rp. 105.229.158,-.

Untuk alokasi biaya pemasaran produk springbed tahun 20132015 adalah sebagai berikut: pada tahun 2013 biaya pemasaran yang terjadi adalah sebesar Rp. 134.780.688, tahun 2014 meningkat menjadi Rp. 138.779.356, dan tahun 2015 meningkat menjadi Rp. $172.853 .100,-$.

3) Profitabilitas

Profitabilitas ini merupakan kelebihan dari hasil penjualan dikurangi dengan biaya pemasaran yang dikeluarkan pada tahun berjalan.Perhitungan ini berlaku untuk semua produk setiap tahunnya. 
Laba kotor yang dihasilkan dari penjualan produk lemari pakaian mengalami kenaikan dari tahun ke tahun.Pada tahun 2013 laba kotor sebesar Rp. 477.000.000, tahun 2014 sebesar Rp. 489.840.000, dan pada tahun 2015 sebesar Rp. 579.700.000.Sama halnya dengan laba kotor yang dihasilkan dari penjualan produk meja rias.Di tahun 2013 laba kotornya sebesar Rp. 228.096.000,-, tahun 2014 sebesar Rp. 324.600.000, dan pada tahun 2015 sebesar Rp. 462.600.00.

Laba kotor dari penjualan produk meja makan juga mengalami kenaikan dari tahun ke tahun.Di tahun 2013 laba kotor sebesar Rp. 396.900.000,-, tahun 2014 sebesar Rp. 501.600.000, dan pada tahun 2015 sebesar Rp. 666.000.000. Begitu pula laba kotor diperoleh dari penjualan produkmeja kerja mengalami peningkatan dari tahun ke tahun.Di tahun 2013 laba kotor sebesar Rp. 228.150.000,-, tahun 2014 sebesar Rp. 334.000.000, dan pada tahun 2015 sebesar Rp. 431.200.000.

Untuk produk kursi, laba kotor yang dihasilkanpada tahun 2013 sebesar Rp. 224.595.000,-, tahun 2014 menurun menjadi sebesar Rp. 193.840.000, dan pada tahun 2015 meningkat menjadi sebesar Rp. 429.692.000.-. Sedangkan laba kotor yang dihasilkan dari penjualan produk springbeddi tahun 2013 sebesar Rp. 1.447.200.000,-, tahun 2014 menurun menjadi sebesar Rp. 1.373.920.000, dan pada tahun 2015 meningkat menjadi sebesar Rp. 3.802.500.000.

\section{KESIMPULAN}

Berdasarkan hasil ringkasan dan penjelasan secara terperinci dari data-data yang tersedia, maka dapat diambil kesimpulan antara lain Alokasi biaya pemasaran setiap jenis produk berdasarkan fungsi pemasaran untuk periode tahun 2013 sampai 2015 cenderung selalu mengalami peningkatan. Analisa biaya pemasaran dan profitabilitas berdasarkan jenis produk tersebut, dapat diketahui bahwa biaya pemasaran yang telah dikeluarkan oleh PT. Kendari Bintang Lestari belum dikelola dengan baik. Hal ini terlihat bahwa biaya yang keluar untuk kegiatan pemasaran banyak digunakan untuk kebutuhan 
karyawan, sedangkan untuk produk hanya sedikit. Dari analisa profitabilitas berdasarkan jenis produk dapat diketahui bahwa produk springbed lebih menguntungkan perusahaan.

\section{SARAN}

Dari kesimpulan yang telah diuraikan, penulis mempunyai beberapa saran untuk PT. Kendari Bintang Lestari Cabang Baubau sebagai bahan pertimbangan.Adapun saran-saran tersebut adalah Untuk memaksimalkan laba perusahaan, maka perusahaan dapat mengalihkan usaha penjualan ke jenis produk yang lebih menguntungkan perusahaan. Mencarikan solusi yang terbaik kepada produk yang tidak terlalu memberikan keuntungan. Mengubah sistem promosi agar lebih mendorong dan menarik konsumen lebih banyak lagi untuk membeli produk.

\section{DAFTAR PUSTAKA}

[1] Basu Swastha, Dharmesta dan Irawan, 2012. Manajemen Pemasaran Modern. Yogyakarta: Liberty.

[2] Kotler, Philips, 2003. Marketing, Management, Analysis, Planning, Control, Jilid 1 Terjemahan Ancella Anitawati Hermawan, Edisi VIII Salemba Empat: Jakarta

[3] Boone, dan Kurtz, 2006. Pengantar Bisnis. Edisi kedua . Jakarta:Erlangga

[4] Kotler dan Amstrong. 2008. Prinsip-Prinsip Marketing Edisi Ketujuh. Jakarta: Erlangga

[5] Subramanyam, K.R dan John J.Wild. 2014. Analisis laporan Keuangan. Penerjemah Dewi.Y. Jakarta : Salemba Empat.

[6] Simamora, Henry, 2001. Akuntansi Bisnis Pengambilan Keputusan. Jakarta: Salemba Empat

[7] Tjiptono, Fandy. 2015. Strategi Pemasaran. Edisi Keempat. Yogyakarta: Andi

[8] Mulyadi, 2005. Akuntansi Biaya. Edisi kelima. Yogyakarta: Salemba Empat.

[9] Sugiyono, 2006. Metode Penelitian Bisnis. Bandung : Alfabeta.

[10] Indriantoro, Nur dan Supomo, 2014. Metodologi Penelitian Bisnis Untuk Akuntansi dan Manajemen. Yogyakarta : BPFE. 
[11] Supriyono , 2000. Akuntansi Biaya : Perencanaan dan Pengendalian Biaya serta Pembuatan Keputusan. Edisi 2. Buku 2. Yogyakarta: BPFE. 